\section{Catabolic Cytokine Expressions in Patients with Degenerative Disc Disease}

\section{Dejeneratif Disk Hastalarında Katabolik Sitokin Salınımı}

\begin{abstract}
AIM: Lumbar degenerative disc disease (DDD) is a common disease of advanced age characterized by progressive changes in the intervertebral disc and associated structures. There have been great efforts for years to explain its pathophysiological mechanism(s). This study aims to provide cytokine profile and in addition to the lymphocytes in a population of patients with lumbar DDD.

MATERIAL and METHODS: Twenty-six patients whose clinical and radiological features were suggestive of lumbar DDD that underwent surgery and 14 autopsy cases as control were included. Patient disc samples were obtained during surgery whilst disc materials were collected during autopsy procedures from the controls. Major cytokines and lymphocytes were studied by using the flow cytometry method.

RESULTS: Significantly higher levels in disc samples in relation to IL-1 $\beta$, IL-2, IL-4, IL-10, IL-12, TNF- $\alpha$, CD8, CD56, CD19, and CD40 were found in the patients compared to the controls. Positive correlations were shown between CD3/CD4, CD25/CD3, CD25/CD4, CD19/CD4 but negative correlations were shown between CD19/CD3 and CD25/CD19 in both groups.

CONCLUSION: The findings suggest that both local inflammatory responses occur in lumbar DDD. Using specific cytokines either by local or systemic application may reverse the degenerative process.

KEYWORDS: Brain hemorrhage, Hemostasis, Magnetic resonance, Microporous polysaccharide hemospheres, Oxidized regenerated cellulose
\end{abstract}

\section{ÖZ}

AMAÇ: Lomber dejeneratif disk hastalığı (DDH) yaşlılı̆̆a bağlı sık görülen bir hastalık olup intervertebral disk ve ilgili yapıların ilerleyici değişiklikleri ile karakterizedir. Hastalığın patofizyolojisin açıklanması için yıllarca büyük gayretler sarfedilmiştir. Bu çalışma, lomber DDH tanısı alan bir grup hastada lenfositler ile birlikte sitokin profilini ortaya koymayı amaçlamıştır.

YÖNTEM ve GEREÇ: Klinik ve radyolojik bulguları DDH tanısını düşündüren ve opere edilen 26 hasta ile 14 otopsi vakasını içeren kontrol grubu çalışmaya dahil edilmiştir. Hastalardan disk materyalleri cerrahi sırasında elde edilmiş, kontrol grubundan ise disk materyalleri otopsi sırasında toplanmıştır. Major sitokinler ve lenfositler akım sitometri yöntemi ile çalışılmıştır.

BULGULAR: Disk materyallerinde hasta grubunda kontrol grubuna gore IL-1 $\beta$, IL-2, IL-4, IL-10, IL-12, TNF- $\alpha$, CD8, CD56, CD19, ve CD40 molekülleri anlamlı olarak yüksek bulunmuştur. Her iki grupta CD3/CD4, CD25/CD3, CD25/ CD4, CD19/CD4 molekülleri arasında pozitif korelasyon saptanırken negatif korelasyonlar CD19/CD3 and CD25/CD19 molekülleri arasında saptanmıştır.

SONUÇ: Bulgular DDH'de lokal inflamasyonun olduğunu düşündürmektedir. Spesifik sitokinlerin lokal veya sistemik uygulamaları dejeneratif süreci tersine çevirebilir.

ANAHTAR SÖZCÜKLER: Dejenerasyon, İnflamasyon, Lenfosit, Lomber disk, Sitokin

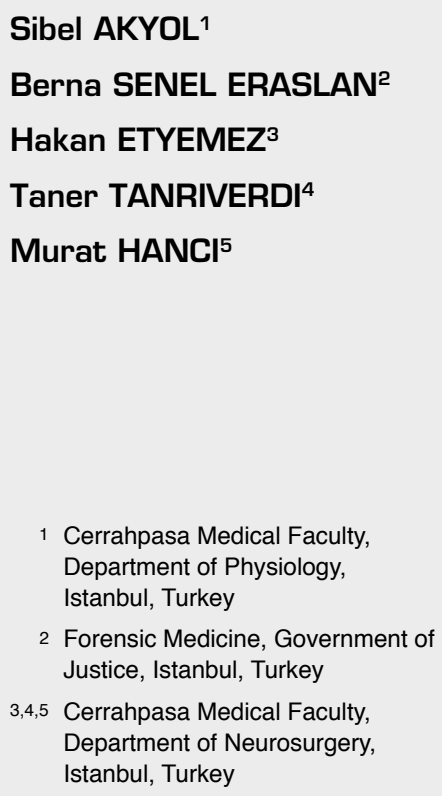

2 Forensic Medicine, Government of Justice, Istanbul, Turkey

3,4,5 Cerrahpasa Medical Faculty, Department of Neurosurgery, Istanbul, Turkey

Received : 18.07.2010

Accepted : 04.08.2010

Correspondence address: Sibel AKYOL

Phone : +90 2124143000

E-mail : sibelakyol@gmail.com 


\section{INTRODUCTION}

When degenerative disc disease (DDD) becomes evident clinically, several symptoms occur that bring the patient to the medical attention, mainly back pain or back pain radiating to the lower extremities and weakness in advanced stage secondary to the nerve root compression. Degenerative disease is a common affliction of the lumbar spine and aging, congenital abnormalities and iatrogenic destabilization, all contributing to the degenerative process. Unlike acute injury, degenerative disease cause slow but progressive changes in the intervertebral disc, facet joints and posterior ligamentous structures that eventually may lead to spondylosis and/or spondylolistesis (9).

It has been clearly shown that although one of the most common causes of DDD is aging, the disorder can be seen in younger individuals as well. As an individual ages, the main component of the discnucleus pulposus, starts to loose its proteoglycan content and the structure surrounding the nucleus pulposus, namely annulus fibrosus, that has rich collagen fibres develops fissures through which the nucleus pulposus herniates. These degenerative processes in turn lead to decrease in the osmotic force drawing water into the disc resulting in a decrease in both the total water content of the disc and the ability of the disc to expand. All these changes invariably present themselves on the radiological examinations as the loss of intervertebral disc space (10, 11, 29). However, the mechanism(s) behind this scenario still await further studies to be defined.

It has been suggested that inflammation may be a factor for explaining the catabolic processes in DDD. The inflammatory cascade in DDD is composed of a highly organized but complex sequential events of molecules which in addition to degraded matrix enzymes include cytokines mainly prostaglandin E2 (PGE2), interleukin-1 (IL-1), IL-2, IL-4, IL-6, IL8, IL-8, tumor necrosis factor- alpha (TNF- $\alpha$ ), and interferon-gamma (IFN- $\gamma$ ). Among the cytokines IL1, IL-6, IL-8, TNF $\alpha$ and PGE2 are the main soluble molecules thought to mediate the catabolic processes $(15,16,30)$.

Studies using modern analysis techniques (30) attempting to determine inflammatory markers in DDD have disclosed that not only mechanical deformation in the disc contents and adjacent structures but also local inflammation in the epidural space involved in the compression and deformation of the nerve roots (2). In DDD, various degrees of hyperinflammatory activities are followed by a period of compensatory hypoinflammation and eventually immunosuppression. During these periods, several abnormalities at the molecular level may be observed such as diminished phagocytosis and intracellular killing activity, diminished monocyte/macrophage activity and reduced immmunoglobin synthesis and cytokine levels in T and B lymphocytes. Although the immune system counteracts to the degenerative changes is known for the decades, there has not been enough available data to explain to what extent the cytokine expressions take place in DDD in the current literature.

The aim of this study was to observe any relative changes between the major pro- (IL-1 $\beta$, IL-2, TNF- $\alpha$, IFN- $\gamma$ ) and anti-inflammatory cytokines (IL-4, IL-10) and lymphocytes and to observe whether there is any effect of the changes in the cytokines on the natural killer (NK) cells and any resultant interactions with IL-12.

\section{MATERIAL and METHODS}

\section{Patients and controls}

This work was conducted at the Neurosurgery and Physiology Departments of Cerrahpasa Medical Faculty, Istanbul University and at the Forensic Medicine Institution, Government of Justice, Istanbul, Turkey. A total of 26 patients (M/F: 16/10) with a mean age of $47.46 \pm 11.25$ years (ranging from 30 to 67 years), who had been admitted to our Neurosurgery Ward due to complaining of sciatica were included. All patients had magnetic resonance imaging (MRI) of the lumbar spine that showed signs of lumbar disc degeneration due tolumbar discherniationsincluding loss of intervertebral disc space, loss of signal intensities, disc herniations and in some cases acute radiculopathy as well. After getting written informed consent from all the patients, surgical treatment was performed. Inclusion criteria in this study were patients who had not undergone a previous spine surgery, and had no systemic chronic disorders such as endocrine or cancer related-disorders. They also had not received epidural steroids, analgesics or anesthetizing agents for any reason.

Disc samples from the patients were obtained during surgery. For the controls, disc samples were taken from the 14 age-matched adult subjects during 
the autopsy procedures that were performed within 24 hours after death. This group included 10 males and 4 females with a mean age of $39.2 \pm 16.4$ years (ranging from 20 to 68 years). Control subjects were included if the death was not caused by a major trauma destroying the anatomical integrity of the spine and spinal cord.

\section{Sample handling}

All specimens were put into polypropylene tubes and kept at $-80{ }^{\circ} \mathrm{C}$ in a liquid nitrogen tank. Lysates from the samples for the cytokines IL-1 $\beta$, IL-2, IL4, IL-10, IL-12, IFN- $\gamma$, TNF- $\alpha$ were analyzed using flow cytometry and Multiple Analyte Platform (XMAP, Lumnex) at Cerrahpasa Faculty Physiology Department Cytokine and Receptor Laboratory.

The following molecular levels were also obtained by flow cytometry: NK (CD56) which plays the major role in defense in the innate immune system, CD3, CD4 (Th), CD8 (Tc) for the cellular immunity and the main cell CD19 (B lymphocyte) along with CD40 and CD25 were analyzed for the humoral immunity.

\section{Tissue preparation}

The lysate method was used after the histogens were unfastened in room temperature. They were smashed in the blender and the obtained suspension was strained from steel filters. Collagenase trypsine was added to the histogenetic suspension for a chemical smash. It was washed in RPMI-1640 solution with FBS after incubation in $37^{\circ} \mathrm{C}$ for one hour. The membrane carver was incubated for 30 moments by adding perm-wash-lysis solution. Later on, the reaction was stopped and put on ice.

\section{Immunofluorescent painting (NK numbers)}

$100 \mu \mathrm{l}$. was taken from the cell suspensions and $10 \mu \mathrm{l}$. fluorescein isothiocyanate (FITC) or phycoerythrin (PE) marked specific antibodies (CD3 FITC, CD16+56+ PE and perforin expression FITC) were added on it. Examples were incubated 10 minutes in room temperature in dark environment and were washed twice with PBS. They were kept until flow cytometric analysis after adding $500 \mu \mathrm{l}$. \% paraformaldehyde.

\section{Flow cytometric method}

The flow cytometric method was used to obtain the percentages of total lymphocytes of the subsets: $\mathrm{CD} 45 / 14, \mathrm{CD} 4\left(_{\mathrm{TH}}\right), \mathrm{CD} 8\left(\mathrm{~T}_{\mathrm{C} / \mathrm{S}}\right), \mathrm{CD} 19(\mathrm{~B}), \mathrm{CD} 56(\mathrm{NK})$, CD25 (IL-2R), CD3 and CD40 counts. Hereafter these parameters will be referred to as CD 45/14, CD4, CD8, CD19, IL-2R, CD56. The following antibodies were used for evaluation of immunophenotyping: CD 45/14 FITC/PE, CD3 FITC , CD4 FITC, CD8 PE, CD19 PE (all from BD Biosciences USA), IL-2R - PE (Pharmingen, USA), CD56 FITC (Serotec, UK). Blood samples were obtained from the patients in lysing solution tubes in which $20 \mu \mathrm{l}$. of monoclonal antibody was incubated at room temperature for 20 minutes. Erythrocytes were separated by adding 1 x $2 \mathrm{ml}$. of mononuclear cell lysing solution (Becton Dickinson, USA) and incubating for 15 minutes. The solution was washed twice with phosphate-buffered saline (PBS) and centrifuged at 1800 RPM. The pellets were then suspended in $100 \mu$ l. of PBS and analyzed with a FACS Calibur instrument (Becton Dickinson) using CellQuest software. A total of 10.000 cells were counted in the lymphocyte gate.

\section{Cartography}

SSC/FSC cartography method was used in our flow cytometric research. However; true cells could be analysed by backgating or consecutive cartography from the cartograph with CD45 for leukocytes which has already performed.

\section{Statistical Analysis}

All data collected from each patient were organized in a database (Excel, Microsoft Corp.). Numeric variables were provided as the mean \pm SD. For statistical analysis, we used the non-parametric Mann-Whitney $U$ test and chi-square test for categorical variables. For correlation analysis, the Pearson correlation was used and a probability value less than 0.05 was considered statistically significant. All statistical calculations were performed using commercially available software (SPSS version 12.0, SPSS Inc.).

\section{RESULTS}

\section{Comparisons}

Table I summarizes the statistical results between the two groups. Patients showed significantly higher levels with respect to the basic cytokines and immune cells on hystogenetic examples from the disc samples; IL-1 $\beta$, IL-2, IL-4, IL-10, IL-12, IFN- $\gamma$, TNF- $\alpha$, CD3, CD4, $\mathrm{CD} 8$, CD56, CD25, CD19, and CD40 compared to the controls $(p<0.05)$. However, no significant differences were found regarding IFN- $\gamma, \mathrm{CD} 3, \mathrm{CD} 4, \mathrm{CD} 56$, and CD25 molecules. In the patients, IL-1 $\beta$ released from monocytes, lymphocytes, and reticuloendothelial 
system cells showed a significant increase in contrast to $\mathrm{CD} 4$ that decreased significantly. As an interesting finding, IL-2 increased significantly although CD4 which is the main source of IL-2, suggesting that IL-2 could have been stimulated by other group of cells. Increase in levels of CD8 and CD19 was thought to be due to the stimulating effects of IL-2 (Figure 1). Given that IL-12 stimulates CD8, CD19, and CD56 to release IFN- $\gamma$ especially from CD8 amd CD56, the findings here seem to be different in that we did not observe a significant and parallel increase in IFN- $\gamma$ and CD56. This could be due to the fact that a large rise in antiinflammatory cytokines IL-4 and IL-10 may have had a negative feedback on IFN- $\gamma$ and CD56 levels (Figure

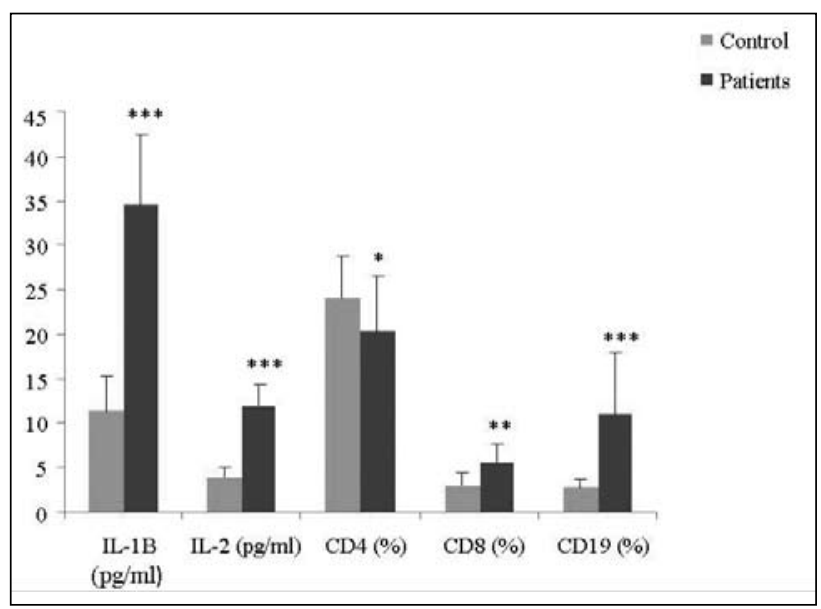

Figure 1: Graphical representations of the changes between the patients and controls regarding pro-inflammatory molecules (IL2 and $I L-1 \beta)$ and $C D 4, C D 8$, and CD19. Note the significant decrease in CD4 and increase in IL-2 levels in patients seems to be unexpected because of the main source of IL-2 is CD4, suggesting that IL-2 could be stimulated by a different group of cells in degeneration process.

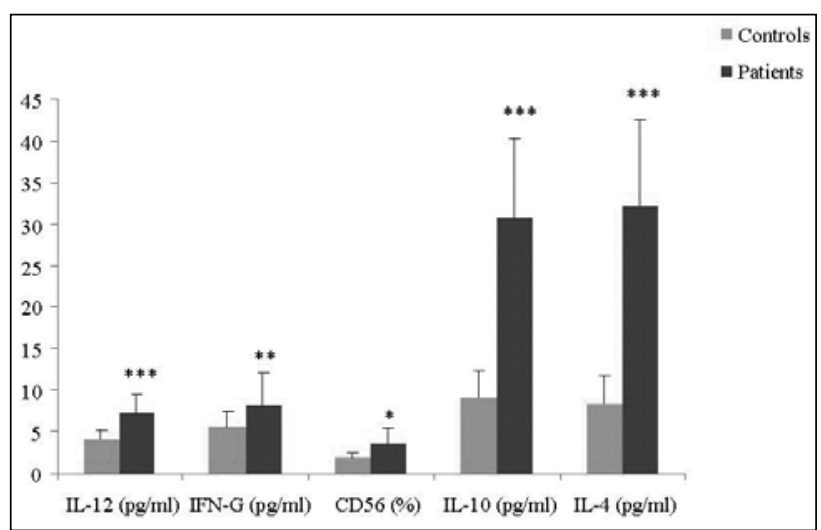

Figure 2: Graphical representation of IL-4, IL-10, IL-12, IFN- $\gamma$, and CD56 levels in the two groups. Very significant increase in $I L-4$ and $I L-10$ levels could be the limiting factors for the release of IL-12, IFN- $\gamma$, and CD56.
2). We determined that the anti-inflammatory (IL-4, IL-10) and pro-inflammatory cytokines, (TNF- $\alpha$, IL$1 \beta$, IL-2) except IFN- $\gamma$ on histogenetic samples of the patients showed a significant increase compared to the controls (Figure 3). CD19 (B lymphocytes), CD8 (expressed on the surface of cytotoxic T cells), IL-2, CD40 significantly increased. However, CD25 (IL-2 receptor) showed a significant decline which probably limits the pro-inflammatory actions of IL-2 (Figure 4).

\section{Correlations}

Correlation analysis showed a highly positive correlation in both patients and controls between

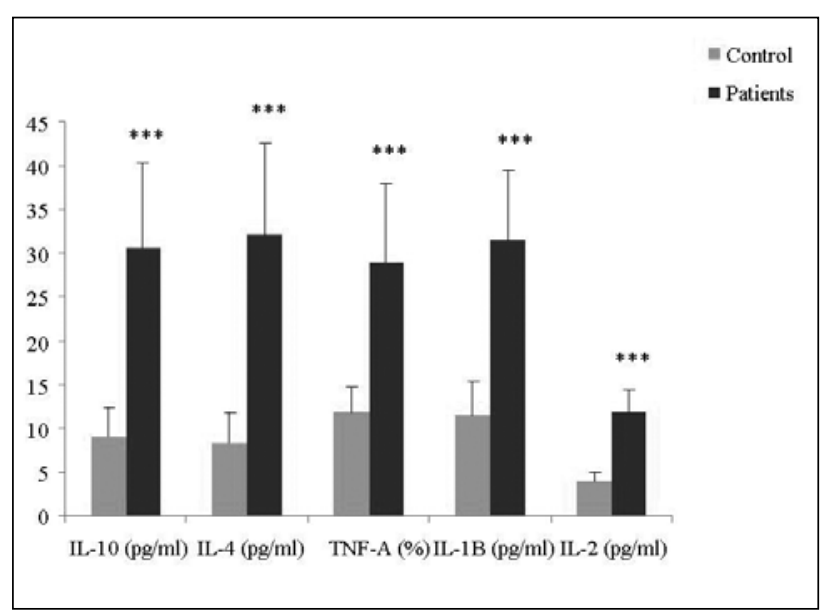

Figure 3: Expressions of major anti-inflammatory (IL-4 and $I L-10)$ and pro-inflammatory (IL-2, IL-1 $\beta$ and TNF- $\alpha)$ in both groups. All the molecules increased significantly in the degenerated disc tissues and IL-10 provides protective effects by inhibiting the mediators such as IL-1 $\beta$, TNF- $\alpha$ and IFN- $\gamma$.

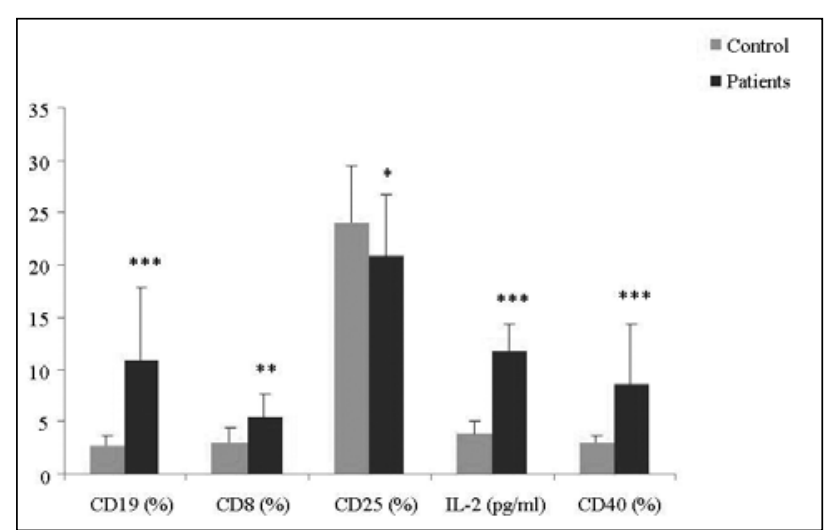

Figure 4: CD19 (B lymphocytes), CD8 (expressed on the surface of cytotoxic T cells), IL-2, CD40 significantly increased. However; CD25 (IL-2 receptor) showed a significant decline which probably limits pro-inflammatory actions of IL-2. 
Table I: A Summary of Statistical Results Showing the Comparisons Regarding the Major Cytokines and Lymphocytes in the Disc Samples Studied Here Between the Two Groups. "p" Values in Bold Stand for Significant Differences ( $<<0.05)$.

\begin{tabular}{|l|c|c|c|}
\hline Variables & Patients & Control & p value \\
\hline Mean age & $47.46 \pm 11.25$ & $37.21 \pm 14.9$ & 0.019 \\
\hline Gender $(\mathrm{M} / \mathrm{F})$ & $16 / 10$ & $10 / 4$ & 0.047 \\
\hline IL-1 $\beta(\mathrm{pg} / \mathrm{ml})$ & $31.61 \pm 7.82$ & $11.45 \pm 3.80$ & 0.0001 \\
\hline IL-2 $(\mathrm{pg} / \mathrm{ml})$ & $11.88 \pm 2.51$ & $3.92 \pm 1.13$ & 0.0001 \\
\hline IL-4 $(\mathrm{pg} / \mathrm{ml})$ & $32.18 \pm 10.38$ & $8.37 \pm 3.35$ & 0.0001 \\
\hline IL-10 $(\mathrm{pg} / \mathrm{ml})$ & $30.67 \pm 9.67$ & $9.09 \pm 3.20$ & 0.0001 \\
\hline IL-12 $(\mathrm{pg} / \mathrm{ml})$ & $7.33 \pm 2.15$ & $4.09 \pm 1.04$ & 0.0001 \\
\hline IFN- $\gamma(\mathrm{pg} / \mathrm{ml})$ & $8.16 \pm 3.95$ & $5.61 \pm 1.82$ & 0.054 \\
\hline TNF- $\alpha(\mathrm{pg} / \mathrm{ml})$ & $28.94 \pm 9.04$ & $11.80 \pm 2.89$ & 0.0001 \\
\hline CD3 $(\%)$ & $25.76 \pm 6.88$ & $28.42 \pm 6.17$ & 0.235 \\
\hline CD4 $(\%)$ & $20.34 \pm 6.26$ & $24.14 \pm 4.62$ & 0.54 \\
\hline CD8 $(\%)$ & $5.53 \pm 2.15$ & $3.00 \pm 1.41$ & 0.001 \\
\hline CD56 $(\%)$ & $3.50 \pm 1.94$ & $1.78 \pm 0.69$ & 0.003 \\
\hline CD25 $(\%)$ & $20.92 \pm 5.87$ & $24.00 \pm 5.46$ & 0.114 \\
\hline CD19 $(\%)$ & $11.00 \pm 6.86$ & $2.71 \pm 1.06$ & 0.0001 \\
\hline CD40 $(\%)$ & $8.57 \pm 5.83$ & $3.00 \pm 0.78$ & 0.0001 \\
\hline
\end{tabular}

$\mathrm{CD} 3 / \mathrm{CD} 4, \mathrm{CD} 3 / \mathrm{CD} 25, \mathrm{CD} 4 / \mathrm{CD} 25$, and CD4/CD19 while CD3/CD19 and CD19/CD25 showed negative correlations.

\section{DISCUSSION}

Many studies have focused on the inflammatory responses, such as cellular infiltrates and proinflammatory cytokines, associated with lumbar disc herniation $(21,26,33)$. The effect of inflammatory responses on the development of radiculopathy has also been studied $(2,12)$. In addition, antibodies and immunoglobulins have been detected in patients with lumbar disc herniation (31-34). In an animal study, autologous nucleus pulposus locally injected into the epidural space has been shown to cause an inflammatory response secondary to the immune reaction (22). It has been reported that herniated lumbar disc tissue spontaneously regresses over time, particularly if the disc fragment has herniated or been into the epidural space (13). The results of the studies mentioned above suggest that immune reactions could play a key role in lumbar DDD.

Although there are several studies in relation to the lumbar disc herniation, no study has yet attempted to investigate the expression(s) of cytokines regarding the immune reactions or immunomodulatory functions.

Antigen specific-mediated responses are triggered by $\mathrm{T}$ lymphocytes. T-cell specific antigen expressing cells may lyse cells or express cytokines that trigger inflammation. Which $\mathrm{T}$ cell response occurs depends on the population such as that in cytotoxic conditions, cytotoxic $\mathrm{T}$ cells $(\mathrm{Tc})$ are active but in delayed hypersensitive conditions helper $\mathrm{T}$ cells (Th) are the major player. Cellular immune system is activated by antigen presenting cells (APCs) that present antigens to $\mathrm{CD}^{+}$and $\mathrm{CD}^{+}$with the cooperation of the presenting peptides by the major histocompatibility complex-I (MHC-I) and -II, respectively. The recognition of the antigen is related to the type of receptors on the Th cells [T cell receptor (TCR), CD4, CD8 or CD3)]. APC's by expressing IL-1 and other cytokines prompt the production of cytokines such as IFN- $\gamma$, IL-2, TNF- $\alpha$ in the Th cells. However; the cytokines released by Th cells by increasing MHCII presentation increase their antigen presenting capacity (20). 
Recent researches show two subgroups of T cells secreting different cytokine profiles after stimulation. On the one hand Th1-type cells secrete high levels of IL-2, TNF- $\alpha$, and IFN- $\gamma$ which in turn activate macrophages and promotes cell-mediated immune responses against invasive intracellular pathogens. On the other hand Th1-type cells also promote the lymphocytes from the bone marrow to secrete IL-3 and granulocyte monocyte colony stimulating factor (GM-CSF) $(28,35)$. Th2-type cells produce a variety of anti-inflammatory cytokines, including IL-4, IL-5, IL-6, IL-10, and IL-13 (20).

Regulatory T cells are the other subgroup of T cells that secrete IL-10 and TGF- $\beta$ at high levels and take a role as immunosuppressives $(8,28,32)$. On the affecter phase of the natural and specific immunity, which are executed by different type of cells, cytokines are able to have an affect on different cells or they have different effects on the same target cells. Some of these effects can occur at the same time or after moments, hour or days (20). It has been demonstrated that two cytokines can lessen (antagonism) or enhance (synergy) the effects of each other or can act in a different manner $(6,7)$. The results from the studies regarding the inflammatory mechanism(s) published previously led us to think that lumbar disc histogen cells can be a source of NK, CD8 cytotoxic cells, proand anti-inflammatory cytokines in degenerative processes. It is reasonable to assume that major proinflammatory cytokines like IL-1 $\beta$, IL- 6 , and TNF- $\alpha$ and anti-inflammatory cytokines such as IL-4, IL-10, IL-13 could play a role for rapid immune responses.

We found that even though IL- $1 \beta$, TNF- $\alpha$, IL2, CD8, CD19, and CD40 levels in the disc samples were significantly higher in patients than those of the controls, the levels of CD3, CD4, CD56, and CD25 (IL-2R) did not show significant changes. Higher levels of IL-2 were correlated with the higher levels of CD8, suggesting that IL-2 stimulated CD8. Interestingly and unexpectedly patients did not have significantly higher levels of CD25 (IL-2R) in their disc samples compared to the controls, which could be explained by the fact that there might have been limited activation of all the cytokines studies here (CD8, CD19, CD56 etc.) or there may be another cascade of the inflammation increasing CD25, which was not addressed in our study. Cytokines act when they bind to their site-specific receptors that could be a suppressor or an activator. As the receptor molecules are attached to the molecular membrane, they can exit freely in solution. One of the most important functions of cytokine receptors is to send an intracellular signal indicating that a cytokine has arrived. The receptor molecule's expression is thus controlled by the cytokine (3-5). However IL-2 expressed by active cells has been reported to increase IL-2 and IFN- $\gamma$ receptor expression and increase IFN and IFN- $\gamma$ production. Our findings are in contrast to above statements that although IL-2 levels were found to be higher in patients than controls, CD25 (IL-2R) and IFN- $\gamma$ levels were almost similar.

IL-1 $\beta$ and TNF- $\alpha$ provides both humoral and cellular responses and causes fast increase in B cell proliferation that was supported by our study. CD19 (B lymphocytes), CD19 surface receptor, T cell activator and CD40 increased significantly. Higher levels of TNF- $\alpha$ affect phagocytes in the disc tissue and stimulate anti-inflammatory cytokines like IL-4, IL-10. In our study this stimulation has been demonstrated. However, it should be noted that increase in IL-4 and IL-10 levels could play an inhibitory role on the feedback and TNF- $\alpha$. Studies have demonstrated that there were some changes in the levels of IL- $1 \beta$, TNF- $\alpha$, and IL- 6 in degenerated disc tissues as a result of the reaction(s) of these immune cells with the other molecules. However; these reactions were noted only in the surroundings of the damaged tissues, not in the whole $(22,24,34)$. IL-2 is a growth factor for CD4 cell and also activates CD56 and CD19 cells. While IL-2 stimulates antibody creation on B cells, it can stimulate CD56 to increase and increasing cytolytic functions at the same time (20). Our findings are somewhat different in which there was no change in CD56 levels although an increase in the levels of CD19, CD40 and IL-2 were noted in the patients.

Several studies have been trying to define and determine the cytotoxic functions of the immunologic cells in DDD. Some studies using pigs have isolated NKcells (CD56) $(23,27)$ and some othersisolated CD19 (B lymphocytes), CD4 (Th), CD56 and macrophages in degenerative disc tissues (14). These results seem to be different from our findings. However; we have to underline that the different results including our own among the studies are mainly due to different methodologies used, the limited number of the patients included or different study population such as animal or human studied. 
Park and co-workers (25) have shown that IL-2, IL-6, IL-8, TNF- $\alpha$ and ATNF-R (alerting to activation tumor necrosis factor receptors) were significantly increased in human degenerated disc samples compared to controls and $\mathrm{CD}^{+}$and $\mathrm{CD} 25^{+} \mathrm{T}$ regulatory cells also played a role in the degeneration. Moreover they stressed that both B and $\mathrm{T}$ lymphocytes were activated in acute lumbar disc herniations but primarily $\mathrm{T}$ lymphocytes were active in case of chronic degenerations. Our results are not in agreement with the above study.

In the current study, comparing the patients with controls revealed both IL-4 and IL-10 had a significant increase in patients. IL-4 and IL-10 have a suppressor effect on TH1 cytokines such as IFN$\gamma$, TNF- $\alpha$, and IL-2. IL-4 stimulates proliferation of Th2 cells from CD4 by making antagonist effect to IFN- $\gamma^{` s}$ macrophage activating effect. IL-19 and IL10 that are released from CD19 and neutrophils have a suppressive effect and play a protective role. They show their protective effect by inhibiting IL-1B, TNF$\alpha$, IFN- $\gamma$, IL-8, and IL-6 mediators $(18,19)$. Our results were different in that increasing of IL-10 and IL-4 did not cause suppression on IL-1B, IL-2, and TNF- $\alpha$. However, increased CD19 and CD40 were reinforced by the increasing of IL-10. The levels of CD3, CD4, and IFN- $\gamma$ did not show any significant change in any tissue groups. This can be explained by the fact that several cytokines can show the same effect $(6,7)$.

Recent studies try to determine immune reactionsmodulating cells namely type-I (Th1) and typeII (Th2), on the one hand and IL-12 expressions in lumbar disc tissue and define immunological status of the degenerated discs on the other hand (12-14, 23).

There has been a continuous interest on the notion that if a herniated lumbar disc tissue has direct contact with macrophages or IL-12 secretion by macrophages it might result in an increase in Th1 and decrease in Th2 activities. It was expressed that the balance between IL-4 and IL-12 designates the type of immune response (type- 1 or type-2) (12, 19, 31). According to our results we may speculate that the degree of IL-I2 expression may be different in degenerated discs; the severity of the injury may have an effect on the determination of the immune status.

Th2 cytokine expression may have precedence on the degeneration processes. When degenerated tissue was compared with cadaver controls in the present study, no change in IFN- $\gamma$ and CD56 (NK) levels but a significant increase in IL-12 were observed.

\section{Study Limitations}

We realize that the main limitation of the current study is that although the study had strict selective criteria that were mainly dependant upon the data from the medical records in the Department of Forensic Medicine regarding the individuals in the control group, we can not be sure that the control cases had no lumbar DDD. Therefore we acknowledge that this limitation could have introduced some bias. It would be very useful if we could provide disc materials from the control population who certainly had no known lumbar DDD for the homogeneity of the study.

\section{CONCLUSION}

This study tried to figure out the main cytokine and lymphocyte profiles and immune reactions in the lumbar degenerated disc tissues. In degenerated discs tissues, an increase in IL-4 and IL-10, both of which inhibitory molecules for type- 1 inflammatory responses, activated the humoral immune system and both molecules showed their inhibitory effects on CD3, CD4, CD25, and CD56 molecules. Degenerated disc tissues led to changes in Th1 and Th2 cytokine expressions and an increase in the IL-12 cytokine level. Anti-inflammatory cytokines predominated in degenerated disc tissues despite the IL-12 increase.

Our results support the notion that immune reactions may play an important role in the degenerative processes in lumbar degenerative disorders and understanding of the cascades involved in degeneration will improve our treatment strategies. Using specific cytokines either by local or systemic application may reverse the degenerative process. Controlling the degeneration will provide benefit to the patients, treating physicians and more importantly decrease the related disability and cost of the treatment of this chronic disease.

\section{REFERENCES}

1. Abbas AK, Murphy KM, Sher A: Functional diversity of helper T lymphocytes. Nature 383: 787-793, 1996

2. Abe Y, Akeda K, An HS, Aoki Y, Pichika R, Muehlemen C, Kimura T, Masuda K: Proinflammatory cytokines stimulate the expression of nerve growth factor by human intervertebral disc cells. Spine 15 :635-642, 2007

3. Abraham RT: Lymhokines and cytokines. Mayo medical school. Immunology course notes, 1992 
4. Balkwill FR, Burke F: The cytokines network. Immunology Today 10: 299-304, 1989

5. Beutler B, Cerami A: The Biology of cachectin/ TNF - $\alpha$ primary mediator of the host response. Annu Rev Immunol 7: 625-655, 1998

6. Bidwell J, Keen L, Gallagher G: Cytokine gene polymorphism in human disease. Genes and Immunity 1: 3-19, 1999

7. Clemens MJ: Cytokines. Oxford: Bios Scientific Publishers,. 57 $-75,1991$

8. Corthay A: How do regulatory T cells work? Scand J Immunol 70: 326-336, 2009

9. Cypress BK: Characteristics of physician visit for back symptoms: A national perspective. Am J Public Health 73: 389-395, 1983

10. Frymoyer JW: Back pain and sciatica. N Engl J Med 318: 291-300, 1988

11. Greenberg MS: Handbook of Neurosurgery. New York: Thieme, 2006

12. Holm S, Mackiewicz Z, Holm AK, Konttinen YT, Kouri VP, Indahl A, Salo J: Pro-inflammatory, pleiotropic, and antiinflammatory TNF-alpha, IL-6, and IL-10 in experimental porcine intervertebral disc degeneration. Vet Pathol 46: 1292-300, 2009

13. Ikeda $\mathrm{T}$, Nakamura $\mathrm{T}$, Kikuchi $\mathrm{T}$ : Pathomechanism of spontaneous regression of the herniated lumbar disc. Histologic and immunohistochemical study. J Spinal Disord 9: 136-140, 1996

14. Jones P, Gardner L, Menaga J, Williams G, Roberts S: Intervertebral disc cells as competent phagocytes in vitro: implications for cell death in disc degeneration. Arthritis Res Ther 10: R86, 2008

15. Kawakami M, Tamaki T, Weinstein JN: Pathomechanism of pain-related behavior produced by allografts of intervertebral disc in the rat. Spine 21: 2101-2107, 1996

16. Kayama S, KonnoS, Olmarker K: Incision of the anulus fibrosus induces nerve root morphologic, vascular, and functional changes: An experimental study. Spine 21: 2539-2543, 1996

17. Lafaille JJ: The role of helper $\mathrm{T}$ cell subsets in autoimmune diseases. Cytokine Growth Factor Revs 9:139-151, 1998

18. Liebig TM, Fiedler A, Klein-Gonzalez N, ShimabukuroVornhagen A, von Bergwelt-Baildon M: Murine model of CD40-activation of B cells. J Vis Exp 5: 1734, 2010

19. Liebig TM, Fiedler A, Zoghi S, Shimabukuro-Vornhagen A, von Bergwelt-Baildon MS: Generation of human CD40-activated B cells. J Vis Exp 16: 1373, 2009

20. Mantovani A, Sozzani S: Chemokines. In: Balkwill F, ed. The Cytokine Network. Oxford: Oxford University Press, 2000, 103-117

21. Marshall LL, Tretherwie ER, Curtain CC: Chemical raduculitis: A clinical, psychological and immunological study. Clin Orthop 129: 61-67, 1987
22. McCarron RF, Wimpee MW, Hudkins PG, Laros GS:The inflammatory effect of nucleus pulposus. A possible element in the pathogenesis of low-back pain. Spine (Phila Pa 1976). 12(8):760-764, 1987

23. Murail K, Sakai D, Nakamura Y, Nakai T, Igarashil T, Seol N, Murakami T, Kobayashi E, Mochida J: Primary immune system responders to nucleus pulposus cells: evidence for immune response in disc herniation. European Cells and Materials 19: 13-21, 2010

24. Paludan SR: Interleukin-4 and interferon $\gamma$ : The quintessence of a mutual antagonistic relationship. Scand J Immunol 48: 459-68, 1998

25. Park MS: The association of the activation inducible tumor necrosis factor receptor and ligand with lumbar disc herniation. Yonsei Med J 31: 839-846, 2007

26. Pennington JR, McCarron RF, Laros GS: Identification of IgG in canine intervertebral disc. Spine 13: 909-912, 1988

27. Podichetty VK: The aging spine: The role of inflammatory mediators in intervertebral disc degeneration. Cell Mol Biol (Noisy-le-grand) 30: 4-18, 2007

28. Romagnani S: Type $1 \mathrm{~T}$ helper and type $2 \mathrm{~T}$ helper cells: Functions, regulation and role in protection and disease. Int J Clin Lab Res 21:152-158, 1991

29. Sato N, Kikuchi S, Sato K: Quantifying the stress induced by distress in patients with lumbar disc herniation in terms of natural killer cell activity measurements. Spine 27: 2095-2100, 2002

30. Scuderi GJ, Brusovamik GV, Greg D: Intervertebral disc herniation and radiculopathy. J Spinal Disord Tech 19: 266-269, 2006

31. Shamji MF, Setton LA, Jarvis W, So S, Chen J, Jing L, Bullock $\mathrm{R}$, Isaacs RE, Brown $\mathrm{C}$, Richardson WJ: Pro-inflammatory cytokine expression profile in degenerative and herniated human intervertebral disc tissues. Arthritis Rheum DOI: 10.1002 / art.27444, 2010

32. Szymczak-Workman AL, Workman CJ, Vignali DA: Cutting edge: Regulatory $\mathrm{T}$ cells do not require stimulation through their TCR to suppress. J Immunol 182: 5188-5192, 2009

33. Takahashi $H$, Suguro $T$, Okazima $Y$ : Inflammatory cytokines in the herniated intervertebral disc tissue. An immunohistochemical study. Eur Spine J 10: 172-176, 2001

34. Weller C, Nerlich AG, Bachemier BE: Expression and distribution of TNF alpha in human lumbar intervertebral discs: A study in surgical specimen and autopsy controls. Spine 30: 44-53, 2005

35. Zhu J, Yamane H, Paul WE: Differentiation of effector CD4 T cell populations Annu Rev Immunol 28: 445-489, 2010 